\title{
A Typological Study of Lower Sorbian ANd Breton Word Order ${ }^{\mathrm{I}}$
}

\author{
Till Vogt
}

\section{Preface}

The present paper offers results of preliminary research on a typological classification of the word order in the traditional varieties of two European minority languages, i.e. Lower Sorbian and Breton, pointing out some major traits they have in common with related languages. For both languages, grammar books describing the traditional literary languages have been analysed in order to determine those grammatical features which are linked to word order.

\subsection{Language contact in Brittany and Lower Lusatia}

Minority languages tend to be exposed to the linguistic impact of their dominating language(s), often for centuries. As a consequence, they are eventually often marginalised and certainly suffer from reduced prestige. ${ }^{2}$ Their use is often pushed back to rural areas, and they are confined to specific contexts and restricted domains of life. Breton and Lower Sorbian, ${ }^{3}$ two European minority languages which are nearly extinct, are two examples for that. Their intergenerational transmission ceased almost completely in the first decades of the $20^{\text {th }}$ century. As for Brittany, the "introduction of free, compulsory and secular elementary education" between

1. I would like to thank Professor Sabine Asmus (Uniwersytet Szczeciński/Universität Leipzig) for helpful advice and suggestions.

2. The sociolinguistic term 'prestige' can be traced back at least as far as Charles A. Ferguson (Ferguson C. A. 1959), who used it in reference to diglossia where the so-called high variety "of two or more varieties of the same language" (id., 232) is considered as "superior to L [a/the low variety] in a number of respects. Sometimes the feeling is so strong that $\mathrm{H}$ alone is regarded as real and $\mathrm{L}$ is reported 'not to exist' " (id., 237). In the present paper, the term 'prestige' is applied to a situation where the language of a minority is regarded as underdeveloped and of lesser value in comparison to the language of the majority: "Bretons have learned that their culture, and language especially, are considered inferior and backward and ridicule has served to reinforce feelings of shame in being Breton" (Kuter 1989: 80).

3. France signed the European Charter for Regional or Minority Languages in 1999 but did not ratify it. Germany ratified the Charter in 1998, and it entered into force in 1999. As determined by the federal state law Gesetz über die Ausgestaltung der Rechte der Sorben/Wenden im Land Brandenburg from 1994, last amended on 15th October 2018, each inhabitant of the so-called 'traditional area of settlement' (angestammtes Siedlungsgebiet) has the right to use the Lower Sorbian language when dealing with officials of the federal state of Brandenburg and its municipal departments. However, the inhabitants have no right to receive a response in Lower Sorbian $(\S 8,2)$. 
1882 and 1887, which came through the medium of French, "the establishment of universal military conscription in 1889 " as well as the extension of the railways, reaching Brest in 1864, harmed the Breton language significantly (Ferguson G. 2006: 95). Furthermore, the mechanisation of agriculture after World War II amplified the depopulation of rural areas in Lower Brittany, i.e. the heartland of the Breton dialects (Ferguson G. 2006: 96).

In Lower Lusatia, the reasons for the collapse of intergenerational language transmission are similar to those in Brittany. From 1815, Lower Lusatia belonged to Prussia, which had already introduced compulsory education, i.e. German-language education, in 1717. However, school attendance of $100 \%$ was not reached before the 1880s (Wittmütz 2007). Other factors contributing to the increasing decline of the Lower Sorbian language from the second half of the 19th century were the beginning of lignite mining (Stefanova 2016: 161) as part of intensive industrialisation going along with fundamental societal changes and the anti-Sorbian governmental policy in the Deutsches Reich after 1871. The linguistic situation got worse when the Nazis prohibited all Sorbian cultural activity, including the publication of Sorbian periodicals, by 1937. After World War II, it was mainly the expansion of opencast mining, the increasing mechanisation of agriculture and the influx of Germans from areas formerly belonging to the Deutsches Reich that detrimentally affected the last strongholds of Lower Sorbian (Spiess 1994: 390).

\subsection{The linguistic impact of the majority language(s)}

According to Sarah Thomason's "Borrowing Scale", there are four possible degrees of language contact: casual contact ("borrowers need not be fluent in the source language, and/or few bilinguals among borrowing-language speakers"), slightly more intense contact ("borrowers must be reasonably fluent bilinguals, but they are probably a minority among borrowing-language speakers"), more intense contact ("more bilinguals, attitudes and other social factors favouring borrowing") and intense contact ("very extensive bilingualism among borrowing-language speakers, social factors strongly favouring borrowing”). (Thomason 2001: 70). Breton and Lower Sorbian are both affected by intense contact. Consequently, they exhibit intensive borrowings both in their lexicon as well as structurally. In their syntax, "sweeping changes" in word order, relative clauses and comparison occur (Thomason 2001: 71). Based on the typological results presented in this article, further research will be dedicated to determine the extent of those sweeping changes in Breton and Lower Sorbian and to the potential development in their learner varieties. 


\section{Word order typology}

Regarding the order of subject, verb and object " in a transitive clause, ${ }^{5}$ more specifically declarative clauses in which both the subject and object involve a noun" (Dryer 2013-1), there are theoretically six permutations possible. ${ }^{6}$ In fact, SVO and SOV are by far the most widespread, followed by VSO. ${ }^{7}$ However, it is not always clear how to classify a language appropriately because the terms used in linguistic literature, i.e. 'dominant word order,' 'surface word order' and 'basic word order', to name but a few, are not clearly defined. ${ }^{8}$ Therefore, I prefer to take a typological approach to classifying the word order of Breton and Lower Sorbian. For the sake of comparison, I cite from studies on the word order of Welsh, which is closely related to Breton, and present a classification of Polish, which is the closest living relative of Lower Sorbian (apart from Upper Sorbian, of course). In addition, the corresponding majority languages-French in the case of Breton and German in the case of Lower Sorbian - are classified. ${ }^{9}$ In the linguistic literature, one finds a wide range of ideas concerning their word order.

4. It is evident that not all sentences entail a subject and/or object. Lower Sorbian, for instance, features sentences without an overt subject, and Breton sentences with periphrastic tenses do not have a direct object, but the logical object occurs as a genitive complement of the verbal noun (cf. Asmus 2016: 115). However, in the present paper I focus on sentences consisting of subject, object and verb.

5. The term 'transitivity' refers "to a verb which can take a direct object" (Crystal 2008: 494). A transitive clause is a clause containing a transitive verb with its direct object.

6. There is disagreement among scholars as to the question of whether to distinguish between these six types or only between VO and OV languages. Dryer (Dryer 1991), for example, mainly differentiates between $\mathrm{VO}$ and $\mathrm{OV}$ languages, suggesting that the order of the verb and the object is more relevant than the order of the verb and the subject. Viewed in this light, SVO and VSO have more in common than SVO and SOV or VSO and SOV. The present paper, by contrast, argues for specific characteristics of verb-initial languages. Therefore, I continue to use the 'classical' terms SVO, VSO and SOV.

7. In the World Atlas of Language Structures, 565 languages were classified as SVO, 488 as SOV and 95 as VSO (Dryer 2013a).

8. Dryer (2013b) differentiates between languages with "rigid word order" and those with "flexible word order". Among the latter, there are languages that have a "dominant word order" and languages that lack a "dominant word order". However, the rule of thumb he presents sounds very arbitrary: "The rule of thumb employed is that if text counts reveal one order of a pair of elements to be more than twice as common as the other order, then that order is considered dominant, while if the frequency of the two orders is such that the more frequent order is less than twice as common as the other, the language is treated as lacking a dominant order for that pair of elements. For sets of three elements, one order is considered dominant if text counts reveal it to be more than twice as common as the next most frequent order; if no order has this property, then the language is treated as lacking a dominant order for that set of elements".

9. A differentiation between the word order of Lower Sorbian and Upper Sorbian is not the subject of this paper, since both languages are closely related and have most word-order-related features in common. Further research needs to be done in order to analyse the impact of Upper Sorbian on 
As for Breton, the classifications given by scholars range from SVO, e.g. Raney (1984: 49): "There is little question that the dominant word order in Modern Breton is SVO"), over VSO (e.g. Timm 1989: 376): "Typologically modern Breton is (or remains) a consistent VSO language [...]", to V2 (e.g. Anderson 2000).

Lower Sorbian, along with Upper Sorbian, is often subsumed under the term 'Sorbian'. Therefore, many descriptions of Sorbian word order do not distinguish between the two languages. Classifications range from SOV, e.g. Starosta (1991: 89): "Die Grundreihenfolge des niedersorbischen Satzes ist: Subjekt - Objekt - Prädikat [...]..." 'The basic order of the Lower Sorbian sentence is: subject - object - predicate [...]', over SVO (e.g. Siewierska \& Uhlírová 1998/2010 and Vogt 2014), to so-called 'free word order', e.g. Muka (1915: 127): ${ }^{10}$

Htowny zakoń za kóźdyžkuli stowosléd w serbšcinje je, zo te stowo, kotrež je abo ma być najbóle wuzběhnjene abo wažene, kajkeježkuli je kategorije (rjadownje), pak na spočatku, pak na kóncu sady stoji.

The main principle for each word order in Sorbian is that the word which is or shall be most emphasised or weighted, regardless of its category (class), appears either at the beginning or at the end of the sentence.

Scholars arguing for a 'free word order' analysis of Sorbian often highlight that it is essentially the information structure of the sentence (topic/theme and comment/ rheme) which determines its word order.

Hence, it is worth defining the word order types found in linguistic literature, always taking the example of a language which is widely recognised to represent the particular type. Thereafter, I proceed with Breton and Lower Sorbian.

\subsubsection{SVO characteristics}

Generally, most SVO languages have the following features in common (Dryer 2007: 68-71):

I Prepositions are used rather than postpositions.

II When comparing two entities, the normal word order is adjective + marker + standard of comparison.

III The genitive complement of a noun phrase follows or precedes it.

Lower Sorbian word order and, probably, also vice versa.

10. Elsewhere, Muka holds the view that in main clauses, the verb tends to appear at the end (Muka 1915: 129). 
IV The adverb is mostly placed after the verb. Though there are several cases where it occurs in front of it.

\subsubsection{French as an SVO language}

Breton's dominating language, French, is a language with a relatively rigid word order that only seldom allows for word order variation. Example (1) is a sentence in the present tense showing SVO order:

(1) Mon grand-père écrit une lettre. my.SG.MASC grandfather write.3.SG.PRES one.FEM letter

'My grandfather writes / is writing a letter.'

When this sentence is put into the passé composé (which is only partly equivalent to the English present perfect), the order of the constituents remains the same: $:^{11}{ }^{12}$

(2) Mon grand-père a écrit une lettre.

my.SG.MASC grandfather have.3.SG.PRES written.SG.MASC one.FEM letter My granfather wrote / has written a letter.

A cleft sentence (mise en rélief) has to be formed in order to emphasise either the subject (example 3) or the object (example 4).

(3) C'est mon grand-père qui écrit une lettre.

this-is my.SG.MASC grandfather RELPRON.SUBJ write.3.SG.PRES one.FEM letter 'It is my grandfather who is writing a letter.'

(4) C'est une lettre que mon grand-père écrit.

this-is one.FEM letter RELPRON.OBJ my.SG.MASC grandfather write.3.SG 'It is a letter that my grandfather is writing.'

The use of cleft sentences for this purpose is an additional trait shared by French

11. In German main clauses containing a nominal or pronominal object, a constituent order where both parts of the periphrastic verb form are placed together is impossible:

Mein Großvater hat einen Brief geschrieben.

my grandfather.NOM.SG have.3.SG.PRES a.ACC.SG.MASC letter.ACC.SG written.

'My grandfather wrote / has written a letter.'

12. Pronominal objects precede the finite part of the verb:

Mon grand-père l'a écrite.

my grandfather PRON.SG.FEM have.3.SG.PRES written.SG.FEM.

'My grandfather has written it.' 
and English as languages with rigid SVO word order. Some scholars provide evidence for the assumption that this is due to Celtic substratum influences (Filppula et al. 2008: 30). In languages with more flexible word order, such as German and the Slavic languages, cleft sentences are rare.

Other SVO features are also well met by French:

I) French is a language with prepositions and does not have postpositions sui generis. Nevertheless, there are some ambipositions, i.e. adpositions that can appear before or after a nominal phrase.

(5) durant trois heures

'during three hours'

(6) trois heures durant

three hours during

'during three hours' / 'for three hours'13

II) In comparative constructions, the only possible word order is adjective + marker + standard of comparison.

(7) L'avion est plus rapide que le train.

the-plane is more fast COMPMARKER the train

'The plane is faster than the train.'

III) The genitive complement generally follows the noun phrase it belongs to.

(8) le fils du roi

the son of-the king

'the son of the king'/'the king's son'

(9) * du roi le fils

of-the king the son

IV) With regard to the position of the adverb, the situation is rather complicated. When modifying a verb, the position of the adverb depends on the tense. In simple-tense constructions (non-periphrastic tenses), the adverb follows the verb.

13. The meaning is basically the same, although stylistic differences are possible: "Durant, prép. de temps, antéposée ou, plus rarement, postposée" ('Durant, preposition of time, preposed or, more rarely, postposed') ('Trésor de la Langue Française informatisé’). 
(10) Mon grand-père mange vite.

my grandfather eat.3.SG.PRES fast

'My grandfather eats / is eating fast.'

(11) *Mon grand-père vite mange.

my grandfather fast eat.3.SG.PRES

In periphrastic tenses, the adverb normally precedes the main verb.

(12) Mon grand-père a vite mangé.

my grandfather have.3.SG.PRES fast eaten.SG.MASC

'My grandfather ate fast / has eaten fast.'

Nevertheless, polysyllabic adverbs tend to come after the main verb like in simple-tense constructions.

(13) Mon grand-père a mangé rapidement.

my grandfather have.3.SG eaten.SG.MASC fast

'My grandfather ate fast / has eaten fast.'

When modifying an adjective or adverb, the adverb in question is normally preposed.

(14) Il mange trop vite.

he eat.3.SG.PRES very fast

'He eats / is eating very fast.'

\subsubsection{SOV features}

SOV languages differ from SVO languages in the following features (cf. Dryer 2007: 61-64):

I Postpositions are used rather than prepositions.

II When comparing two entities, the normal word order is standard of comparison + marker + adjective.

III The genitive complement of a noun phrase normally precedes the noun phrase.

IV The adverb is mostly placed in front of the verb. 


\subsubsection{Hindi as an SOV language}

Among many other Indo-Aryan languages, Hindi is a language with a relatively rigid SOV word order. In simple declarative sentences, the verbal expression is placed at the end.

(15) Dādājī patra likb rahe haĩ.

grandfather.HON letter.ABS write.ROOT stay.PAST.PART.PL.MASC be.3.PL.PRES

'Grandfather is writing a letter.'

What is more, the grammar of Hindi exhibits further typical features of SOV languages as mentioned above.

I) Postpositions are used instead of prepositions.

(16) mere sāth

I.POSS.OBL with

'with me'

(17) ghar se andar

house from outside

'outside the house'

II) The normal word order in comparative structures is standard of comparison + marker + adjective.

(18) Rām Surés se baḍa hai.

Ram Suresh COMP big.ABS.SG.MASC be.3.SG.PRES

'Ram is older than Suresh.'

III) Except in poetry, the genitive complement has to precede the noun phrase.

(19) mere bhā̄ kā kuttā

I.POSS.OBL.SG.MASC brother POSS.ABS.SG.MASC dog

'the dog of my brother'/'my brother's dog'

IV) Furthermore, the adverb generally precedes the word it refers to. 
(20)

\author{
Dädājī acchā gäte haĩ. \\ grandfather.HON well sing.PRESPART.PL.MASC be.3.PL.PRES \\ 'Grandfather sings well.'
}

\title{
2.4.1. VSO characteristics
}

An early typology of VSO languages can be found in Greenberg (1963). He was followed, inter alios, by Ouhalla (1991), Carnie \& Guilfoyle (2000), and Borsley et al. (2007). In this section, I list a selection of those VSO features which seem to be relevant for the discussion of Breton in paragraph 3. Although some features are not shared by all VSO languages of the world,$^{14}$ they seem to be significantly frequent in VSO languages (cf. Borsley et. al. 2007: 350):

I The genitive complement generally follows the noun it refers to.

II There is no number agreement between a plural full noun phrase subject and the finite verb.

III Various preverbal particles are used.

IV Prepositions are inflected.

V Apart from the above-mentioned features, a lot of VSO languages, including all Insular-Celtic languages, lack a lexical expression for 'to have. ${ }^{15}$ However, this is also the case in several non-VSO languages like Russian and other Slavic languages or Hindi. ${ }^{16}$

\subsubsection{Welsh as a VSO language}

Any non-emphatic declarative sentence in Welsh features an initial finite verb. ${ }^{17}$

14. Apart from the Insular Celtic languages, many Afro-Asiatic languages, Austronesian languages and some Meso-American languages are described as VSO languages.

15. This was already noticed by Greenberg, who analysed African languages which were all used by tribal societies. The concept of possession beyond personal belongings is not normally developed in such societies and therefore not encoded linguistically. Hence, we see here the confusion of societal and linguistic concepts.

16. Although the lack of a lexical expression for possession is not specific to VSO languages, all Insular Celtic languages exhibit this feature. Hence, it is listed here and discussed in chapter 2 with regard to Breton.

17. Today, such sentences are ungrammatical in Breton: * Lennas ma zad-kozh ul levr. read.3.SG.PAST my father-old a book 'My grandfather read a book.' Instead, a periphrastic construction can be used 
Other features of VSO languages are also found:

I) The genitive complement has to follow the noun it refers to and cannot precede it.

(21) llyfr y disgybl book the pupil

'the book of the pupil' / 'the pupil's book'

(22) * ${ }^{*}$ disgybl llyfr the pupil book

II) The subsequent example displays the lack of number agreement between the finite verb form diflannodd and the subject.

(23) Diflannodd/*diflannon y dreigiau. disappear.3.SG.PAST/disappear.3.PL.PAST the dragons 'The dragons disappeared.' (Borsley et al. 2007: 356)

III) The finite verb must precede the subject. In absolute initial position, a preverbal particle can be overt in order to indicate a declarative sentence.

\section{(24) $\mathbf{F e} / \mathrm{Mi}$ ddarllenafi.}

AFF read.1.SG I

'I read.'

However, there are sentences like the following (25) where no particle is articulated. Nevertheless, the soft mutation of initial $/ \mathrm{k} /$ takes over the function of the preverbal particle as in sentence 24 .

(25) Gafodd hi anrheg ddoe.

get. 3.SG.PAST she gift yesterday

'She received a gift yesterday.' (cf. Bury 2005: 149)

IV) Most prepositions are inflected. As an example, the full paradigm of the preposition at 'to' is given: 
$1 \mathrm{SG}$ ataf

2 SG atat

$3 \mathrm{SG} \mathrm{m}$ ato

$3 \mathrm{SG} \mathrm{f}$ ati

$1 \mathrm{PL}$ atom

2 PL atoch

3 PL atynt

V) In terms of linguistic devices to express possession, Welsh clearly indicates that it lacks a lexical equivalent for the English verb 'to have'. The following expressions are used in Welsh:

(26) Y mae gennyf gar.

AFF be.3.SG.PRES with.1.SG car

'I have a car.'

(27) Y mae annwyd arnaf.

AFF be.3.SG.PRES cold on.1.SG

'I have a cold.'

(28) Yr wyf ag arian.

AFF be.1.SG.PRES with money

'I happen to have money.'

(29) Y mae arian iddo.

AFF be.3.SG.PRES money to.3.SG.MASC

'There is money for him.'

\subsection{V2 languages}

Except for English, the Germanic languages are known to feature a word order distinct from those discussed above. This characteristic word order implies that, at least in certain sentence types, the finite part of the verb comes second in the sentence, while the non-finite part (e.g. participles, infinitives) occurs in final position. The V2 languages differ in terms of the sentence types in which V2 order is applied. In German, for instance, V2 is used in simple declarative sentences, whereas in embedded sentences, all the parts of the verb are placed at the end of the sentence with the result that the word order here resembles SOV. 
(30) Mein Großvater will einen Brief schreiben.

my grandfather want.3.SG.PRES a.ACC.SG.MASC letter write.INF

'My grandfather wants to write a letter.'

(31) Sie sagt, dass mein Großvater einen Brief schreiben will.

she say.3.SG.PRES that my grandfather a.ACC.SG.MASC letter write.INF want.3.SG.PRES

'She says that my grandfather wants to write a letter.'

\section{6. 'Free word order' and 'free' SVO}

Slavic languages are abundant in morphological marking. Given that the relations between the constituents of a sentence are well expressed by morphological means, Slavic languages permit substantial variation in their word order for the purposes of information structure. This is why they are often regarded as languages with so-called 'free word order'. However, there often seems to be one word order that is perceived as the most neutral one. In addition to that, a typological examination leads to the conclusion that most of them are in fact SVO languages (sometimes also called 'free SVO languages'), (cf. Siewierska et al. 1998: 107). Most scholars agree with such an analysis. This paragraph is concerned with Polish as, except for Upper Sorbian, it is the language which is most closely related to Lower Sorbian. It becomes apparent that Polish has much more in common with SVO languages than with SOV languages:

I) As is typical of SVO languages, the grammar of Polish merely exhibits prepositions. Postpositions are not used.

(32) wzdtuz rzeki

along river.GEN.SG

'along the river'

(33) * rzeki wzdtuż

river.GEN.SG along

II) When two things are compared, the only possible word order is adjective + marker + standard of comparison. Given the two equivalents for 'than', two constructions are possible:

(34) Ten budynek jest wyższy niż tamten. this.NOM.SG.MASC building.NOM.SG be.3.SG.PRES higher.NOM.SG.MASC than that-one.NOM.SG.MASC 
(35) Ten budynek jest wyższy od tamtego.

this.NOM.SG.MASC building.NOM.SG be.3.SG.PRES higher.NOM.SG.MASC from that-one.GEN.SG.MASC

'This building is taller than that one.'

III) The genitive complement has to follow the noun phrase and does not precede it:

It is important to note the WORD-ORDER: in normal style in Polish the POSSESSED object occurs first and the POSSESSOR second whereas in English with possessive constructions in 's the situation is reversed.

(Brooks 1975: 125)

The following is an example:

(36) dom mojego ojca house my.GEN.SG.MASC father.GEN.SG 'the house of my father' / 'my father's house'

However, in order to express a possessive relation, the genitive complement can also be substituted by a possessive adjective that precedes or follows the noun phrase (Brooks 1975: 124):

(37) ojcowski dom father.POSSADJ.NOM.SG.MASC house.NOM.SG

'father's house'

(38) ulicy Warszawskie streets.NOM.PL Warsaw.POSSADJ.NOM.PL.FEM 'the streets of Warsaw' / 'Warsaw's streets'

IV) The adverb can be placed before or after the verb.

(39) Dziadek źle styszy. grandfather.NOM.SG bad.ADV hear.3.SG.PRES

(40) Dziadek styszy źle. grandfather.NOM.SG hear.3.SG.PRES bad.ADV 'Grandfather is hard of hearing.' 


\section{Traditional Breton as a VSO language}

For the purposes of this paper, the term 'Traditional Breton' designates the variety of Breton that was developed as a standard on the basis of the dialect Leoneg from the $17^{\text {th }}$ century onwards. It was used for the translations of biblical texts, such as the New Testament, 'Testamant nevez hon aotrou Jézuz-Krist' (1827), and the Old Testament, 'Testamant Kozh' (1866), by Fañch Le Gonidec. The 'Dictionnaire Bretonfrançais' with a preceding grammar as well as the 'Dictionnaire Français-breton' by Théodore Hersart de la Villemarqué (1847-1850), which was an extension of Le Gonidec's 'Dictionnaire celto-breton' from 1821, can also be considered landmarks in the development of a codified language. It was the Emgleo ar Skrivagnerien 'the Union of Breton Writers' which set the north-western pole of the Breton dialect continuum 'KLT' (so called because it consisted of the dialectal varieties Kerneveg, Leoneg and Tregerieg) as a new, broader standard in 1907. This standard was later promoted by the highly productive linguist Roparz Hemon (alias Louis Paul Némo, 1900-1978), who, although not being a native speaker of Breton, wrote grammars, dictionaries, schoolbooks, textbooks, dramas and stories in Breton, immediately applying standardisation to the language he was using. Moreover, he translated world literature into Breton, enhancing its literary canon. ${ }^{18}$

Of those Breton grammars ${ }^{19}$ addressing word order issues, three were selected and are presented here: Kervella (1947), Trépos (1966), Chalm (2008).

François Kervella (1913-1992), in his grammar Yezhadur Bras ar Brezhoneg, formulated 'three golden rules of Breton syntax' (Kervella 1976: 389):

1. Ar ger (pe an ezel frazenn) a venner pouezañ warnañ a zeu atav da gentañ.

2. Ar verb a zeu da eil.

3. N'hell ket ar verb dindan e stumm personnel (da lavarout eo gant ar rannoùigoù a pe e dirazañ) bezañ e penn ar frazenn.

1. The word (or the sentence constituent) which shall be emphasised comes always first.

2. The verb comes in the second position.

3. The verb in its personal form (i.e. preceded by the preverbal particle $a$ or $e$ ) can not appear at the beginning of the sentence.

18. To the present day, his work has not been fully accepted due to his collaboration with Nazi officials.

19. A list of major Breton grammars is given in (Vogt 2019: 144-145). 
He then gives examples for the different types of clauses (verb at the beginning, subject at the beginning, predicate adjective at the beginning, object at the beginning, adverbial at the beginning) (Kervella 1976: 390-395).

Pierre Trépos (1913-1966), in the chapter L'Ordre des Mots 'Word Order' of his posthumously published grammar, expressly underlines the flexibility of arranging the sentence constituents:

La phrase bretonne, nous l'avons senti, est très flexible et offre des ressources dans le domaine de l'expressivité. La richesse des formes de la conjugaison, la compréhension très large de la notion relative, la souplesse générale de la syntaxe (qui ne veut pas dire relâchement), autorisent des constructions très diverses et qui pourraient sembler audacieuses en toute autre langue. [...] Le mot essentiel sur lequel on veut attirer l'attention, celui qui révèle aux mieux la pensée de l'auteur ou ses intentions implicites, peut toujours se placer en tête.

(Trépos 1980: 272)

The Breton sentence, as we have seen now, is very flexible and offers a lot of possibilities in the domain of expression. The abundance of inflectional forms of the verb, the very broad understanding of the relative notion and the general pliability of the syntax (not that the syntactical rules were relaxed) allow for various constructions that would sound very audacious in every other language. [...] The essential word the attention shall be directed to, the one which best reveals the idea of the author or his implicit intentions, can always be placed at the beginning.

In order to demonstrate this rule, he gives six possible arrangements of the sentence constituents Perig 'Pete' (subject), bezañ o klask 'to be looking for' (verb), e vreur 'his brother' (object), er c'hoad 'in the forest' (adverbial) along with their French equivalents (Trépos 1980: 272-273):

(41) Perig a zo o klask e vreur er c'hoad.

Peter.DIM PTCL be.3.SG.PRES PTCL look-for.VERBNOUN his brother in.DEF forest Petit Pierre est à chercher son frère dans le bois.

little Peter be.3.SG.PRES at look-for.INF POSS.3.SG.MASC brother in the forest

'Pete is looking for his brother in the forest."20

The subject can be highlighted even more when using the construction an hini eo 'to be the one (who)':

20. However, Trépos (1980: 274) claims that Breton generally avoids to put the subject sentenceinitially unless it is emphasised. 
(42) Perig 'ni eo a zo o klask e vreur er c'hoad.

Peter.DIM the-one be.3.SG.PRES PTCL be.3.SG.PRES PTCL look-for.VERBNOUN his brother in.DEF forest

C'est Perig qui est à chercher son frère dans le bois.

this-be.3.SG.PRES Perig RELPRON be.3.SG at look-for.INF POSS.3.SG.MASC brother in the forest

'Perig is the one / It is Perig who is looking for his brother in the forest.'

The action can be emphasised:

(43) O klask e vreur ema Perig er c'hoad.

PTCL look-for.VERBNOUN his brother be.3.SG.SIT.PRES Peter.DIM in.DEF forest

C'est à chercher son frère que Perig est occupé dans le bois.

this-be.3.SG.PRES at look-for.INF POSS.3.SG.MASC brother that Perig be.3.SG. PRES occupied.SG.MASC in the forest

'It is looking for his brother that Perig is occupied with in the forest.'

The object can be emphasised:

(44) Evreur ema Perig o klask er c'hoad.

his brother be.3.SG.SIT.PRES Peter.DIM PTCL look-for.VERBNOUN in.DEF forest

C'est son frère que Perig est en train de chercher dans le bois.

this-be.3.SG.PRES POSS.3.SG.MASC brother RELPRON Perig be.3.SG.PRES in train of look-for.INF in the forest

'It is his brother whom Perig is looking for in the forest.'

The adverbial can be emphasised:

(45) Er c'hoad ema Perig o klask e vreur.

in.DEF forest be.3.SG.SIT.PRES Peter.DIM PTCL look-for.VERBNOUN his brother

C'est dans le bois que Perig est en train de chercher son frère.

this-be.3.SG.PRES in the forest that Perig be.3.SG.PRES in train of look-for.INF POS-

S.3.SG.MASC brother

'It is in the forest that Perig is looking for his brother.'

The progressive tense can be emphasised: 
(46) Ema Perig o klask e vreur er c'hoad.

be.3.SG.SIT.PRES Peter.DIM PTCL look-for.VERBNOUN his brother in.DEF forest Voilà que Perig est en train de chercher son frère dans le bois.

behold! that Perig be.3.SG.PRES in train of look-for.INF POSS.3.SG.MASC brother in the forest

'Perig is now looking for his brother in the forest.'

Both the progressive tense and Perig's presence in the forest can be emphasised:

(47) Bez' ema Perig o klask e vreur er c'hoad.

be.3.SG.HAB.PRES be.3.SG.SIT.PRES Peter.DIM PTCL look-for.VERBNOUN his brother in.DEF forest

En ce moment, Perig est occupé à chercher son frère dans le bois.

in this moment Perig be.3.SG.PRES occupied.SG.MASC at look-for.INF POSS.3.SG. MASC brother in the forest

'At this very moment, Perig is looking for his brother in the forest.'

Furthermore, using the sentence 'I read the book / I am reading the book' Trépos (1980: 274) shows possible conjugation patterns when using the finite verb in a sentence: the personal pattern al leor a lennan (the book PTCL read.1.SG.PRES), the impersonal pattern me a lenn al leor (I PTCL read.3.SG.PRES the book), the frequentative pattern lennet vez al leor ganin (read.PASTPART be.3.SG.HAB.PRES the book with.1.SG.PRES), the progressive pattern emaon o lenn al leor / o lenn al leor emaon (be.1.SG.SIT.PRES PTCL read. VERBNOUN the book / PTCL read.VERBNOUN the book be.1.SG.SIT.PRES). Although the third sentence using the frequentative pattern has no overt particle, the mixed mutation form vez shows us that the verbal particle $e$ is omitted here.

Also Eugène Chalm (1909-2002) points to the many possible ways of arranging the sentence constituents in order to highlight the initial one:

Le verbe conjugué, normalement précédé de la particule verbale a ou e, vient toujours en seconde position. [...] Toutes ces phrases pourraient être traduites par Mon père achète le journal tous les jours à la boutique, mais, en breton, on met en premier l'élément que l'on estime être le plus important à faire connaître à son interlocuteur.

(Chalm 2008: 198)

The conjugated verb which is normally preceded by the verbal particle $\mathbf{a}$ or $\mathbf{e}$, always appears in the second position. [.... ${ }^{21}$ All these phrases could be translated as My father buys the

21. Chalm gives the following arrangements of the constituents ma zad 'my father', pren/bren 'buy', ar gazetenn 'the newspaper', er stal 'in the shop' and bemdez 'every day': Ma zad a bren ar gazetenn er stal bemdez. / Bemdez e pren ma zad ar gazetenn er stal. / Ar gazetenn a bren ma zad er stal bemdez. / Er stal 
newspaper in the shop every day, but the Breton speaker puts the element which is considered to be the most important for the interlocutor at the beginning of the sentence.

Chalm (2008: 198-199) further explicitly mentions the exceptions where the finite verb may occur sentence-initially. These are the following:

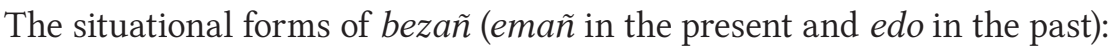

(48) Emañ ma zad o prenañ ar gazetenn er stal. be.3.SG.SIT.PRES my father PTCL buy.VERBNOUN the newspaper in.DEF shop Mon père est en train d'acheter le journal. my.MASC father be.3.SG.PRES in train of-buy.INF the newspaper 'My father is buying the newspaper in the shop.'

(49) Edont er gêr d'an ampoent. be.3.PL.SIT.IPF in.DEF home to-the moment Ils / elles étaient à la maison à ce moment-là. they.MASC / they.FEM be.3.PL.IPF at the house at this moment-there 'They were at home at that moment.'

In imperative sentences, the finite verb comes first:

(50) Sellit ouzh ar pezh emañ o tiskouezh! look.2.PL.IMP to the thing be.3.SG.SIT.PRES PTCL show.VERBNOUN Regardez ce qu'il / elle est en train de montrer! look.2.PL.IMP this RELPRON-he / -she be.3.SG.PRES in train of show.INF 'Look at what he / she is showing you!'

Interjections based on imperatives:

(51) Sell 'ta! look.2.SG.IMP MOD

Tiens donc! hold.2.SG.IMP MOD 'Look at this!'

Responses to negative interrogative sentences or contradictions based on the same scheme: (52) Eo!

\footnotetext{
e pren ma zad ar gazetenn bemdez. / Prenañ a ra ma zad ar gazetenn er stal bemdez.
} 
be.3.SG.PRES

Si!

so

'On the contrary!'

(53) Ne vo ket amzer da vont? - Bo!

not be.3.SG.FUT NEG time to go.VERBNOUN? be.3.SG.FUT!

On n'aura pas le temps d'y aller? - Si!

INDEFPRON not-have.3.SG.FUT PTCL the time to-there go.INF? so!

'Isn't it about time to go? Yes, it is.'

(54) Eo 'vat!

be.3.SG.PRES though

Que si!

that so

'Of course!'

Quick rejoinders where the sentence begins with the finite verb which is only preceded by the preverbal particle:

(55) A c'hallfe bezañ!

PTCL can.3.SG.COND.PRES be.VERBNOUN

Ça se pourrait!

that REFL can.3.SG.COND

'That could be!'

(56) Meus aon.

of-me be.3.SG.PRES fear

Je le crains.

I he fear.1.SG.PRES

'That's what I fear.'

Sometimes, forms of the verb mont 'to go' introduce the sentence, being only preceded by the preverbal particle $e z$ :

(57) Ez an da vont bremañ.

PTCL go.1.SG.PRES to go.VERBNOUN now

Je vais y aller maintenant.

I go.1.SG.PRES there go.INF now

'I will go there now.' 
Breton syntax, as described in the grammars above, displays most of the features characteristic for VSO languages presented in paragraph section 2.4.1. The examples given below substantiate the hypothesis that traditional Breton is typologically indeed a VSO language:

I) In Breton, like in Welsh, the genitive complement has to come after the noun phrase. This distinguishes Breton from the majority of SVO languages, which allow both NP + Genitive and Genitive + NP.

(58) mab ar roue

son the king

'the son of the king' / 'the king's son'

(59) *ar roue mab

the king son

II) Breton lacks subject-verb agreement in number when there is an overt nominal subject.

(60) Ar vugale a lenn levrioù.

the children.PL PTCL read.3.SG books.PL

(61) Lenn a ra ar vugale levrioù.

read PTCL do.3.SG the children.PL books.PL

(62) Levrioù a lenn ar vugale.

books.PL PTCL read.3.SG the children.PL

'The children read books.'

III) Breton word order differs from Welsh word order in so far as there are only a few cases where the finite verb is permitted to occur at the beginning of a sentence. ${ }^{22}$ However, any other sentence constituent may appear in this position. The finite verb following in the second position has to be preceded by a preverbal particle which functions as a syntactical marker indicating the first sentence constituent. After subjects, direct objects or verbal nouns, it is the particle $a$, which causes lenition (Press 1986: 197).

22. For an overview including traditional Breton and Carhais Breton, a spoken variety, cf. Timm (1989): 365. 
(63) Mona a zebr he boued er gegin.

Mona PTCL eat.3.SG her food in.DEF kitchen

(64) He boued a zebr Mona er gegin.

her food eat.3.SG Mona PTCL in.DEF kitchen

(65) Debriñ a ra Mona he boued er gegin.

eat.VERBNOUN PTCL do.3.SG Mona her food in.DEF kitchen

'Mona eats her meal in the kitchen.'

Elsewhere (e.g. after adverbial phrases) the particle $e$ is used and causes mixed mutation.

(66) Er gegin e tebr Mona he boued.

in.DEF kitchen PTCL eat Mona her food

'Mona eats her meal in the kitchen.'

However, sentence 65, in which the verbal noun is fronted and followed by the auxiliary verb ober 'to do', is sometimes regarded as the most neutral one. ${ }^{23}$ When the other constituents of the sentence (the subject in 63, the object in 64, the adverbial in 66) are fronted, they are perceived as emphasised (focalised) (Press 1986: 187).

IV) Like in the other living Celtic languages, Breton prepositions are inflected according to number and person. Constructions like *da me ('to me') are ungrammatical. For demonstration, I give the complete paradigm of the preposition $d a$ 'to':

$1 \mathrm{SG}$ din

$2 \mathrm{SG} d i t$

3 SG m dezhañ

3 SG f dezhi

$1 \mathrm{PL}$ deomp $(\operatorname{dim} p)$

2 PL deoc'h

3 PL dezho (dezhe)

Impersonal deor

V) As distinct from other Celtic languages, Breton has a quasi-lexical expression for 'to have' - kaout (and in the dialect of Gwened/Vannes, endevout). This expression, however, is only quasi-lexical since the forms of the paradigm developed

23. This assumption is highly controversial and cannot be judged here. 
from personal pronouns and (ez) eus - a third person singular form of bezañ 'to be'. In addition, there are also other ways to express possession in Breton. In particular when indicating the temporary possession of a mobile item, a construction consisting of the third person singular of 'to be' (indefinite ez eus or definite emañ) and the preposition gant 'with' is used.

(67) N'eus ket eur gontell ganit? ? $^{24}$

not-is NEG a knife with.2.SG

'Don't you have a knife (with you)?'

\section{Traditional Lower Sorbian as a free SVO language}

The literary tradition of Lower Sorbian goes back to the $16^{\text {th }}$ century, when Mikławš Jakubica produced the first translation of the New Testament into one of the Lower Sorbian dialects. ${ }^{25}$ From this time onwards, several biblical texts and gospels were translated into the dialects of Lower Sorbian. The first printed Sorbian book, The Small Catechism, along with a hymnal translated and compiled by Albin Moller and published in 1574, was in Lower Sorbian. ${ }^{26}$ Jan Bogumił Fabricius was the author of the first translation of the New Testament that appeared in print, i.e. Das Neue Testament Unsers HErrn JEsu Christi in die Nieder-Lausitzsche Wendische Sprache übersetzet (1709), and Jan Bjedrich Fryco added the first printed version of the Old Testament, Bože Pißmo Starego Testamenta (1796). A major role in creating and publishing secular texts was played by the newspaper (Bramborski) Serski Casnik from 1848. Its successor Nowy Casnik is a weekly newspaper still appearing today. The current chief editor, Gregor Wieczorek, makes great efforts to draw on the traditions of its precursor, at least concerning the language. The earlier literary tradition ceased abruptly in 1933, when the newspaper was prohibited by Nazi officials. Finally, the use of Sorbian in public and all Sorbian associations were forbidden in 1937. Due to the increasing linguistic influence of Upper Sorbian and German on Lower Sorbian after World War II, the Sorbian intellectual elite failed to re-establish

24. Taken from Jules Gros (1966).

25. This was a Lower Sorbian dialect spoken around Žarow (today Żary in Poland), located circa 30 kilometres to the east of the present-day border river Nysa/Neiße. Sorbian dialects to the east of the contemporary border with Poland have been extinct since the beginning of the 20th century. A comprehensive description of this dialect can be found in Ščerba (1915).

26. The full title is 'Ein Ewigwerender Kirchen Calender wie man den Sontags Buchstaben, die Zeit zwischen dem Christage vnd Fastnacht gründtlichen erfinden möge. Auch ein Wendisches Gesangbuch, darinnen auf die Hohe Fest die Introitus, Kyrie, \& præfationes, in Lateinischer vnd Wendischer Sprache vnd die Geistliche Lieder auch etliche Psalmen Reimweise begriffen neben den Gebetlein. Auch der kleine Catechismus mit dem Tauff und Träuwbüchlein Wendisch vertiret.' (cf. 
the previous literary language and to draw on the literary traditions that existed before 1933. Up to the present day, there is much disagreement about what should be regarded as appropriate Lower Sorbian. One of the main issues under discussion is the word order used in current written and spoken Lower Sorbian. Since most people writing in Lower Sorbian today did not learn the language at home, an increasing influence from German or Upper Sorbian can be observed. The objective of this section is to show that traditional Lower Sorbian is a free SVO language, similar to Polish, in the sense of section 2.6.

The earliest statement that might refer to word order can be found in the first Lower Sorbian grammar by Jan Chojnan from 1650 (which is also the earliest Sorbian grammar):

Syntactiva doctrina superflue adderetur: in plurimis $n$. Ductum Lingvae Latinae et Teutonicae seqvitur, qvi iam passim ostensus est.

(Lotze 1862)

It is not necessary to present syntax [here] because [Lower Sorbian] follows the frequently mentioned pattern of Latin and German. ${ }^{27}$

Later, the famous Sorbian grammarian and lexicographer Arnošt Muka wrote the following in an article about Sorbian word order in 1915:

W pohladźe na potoženje stowjesa njeje w serbšćinje mjez htownymi a pobočnymi sadami žadyn rozdźél.

(Muka 1915: 128)

Regarding the position of the verb in Sorbian, there is no difference between main clauses and embedded clauses.

It was more than half a century after Muka that Frido Michałk (1970) did research on Upper Sorbian and Lower Sorbian dialects. He observed that both languages differ significantly in regard to word order. He comes to the result that the so-called verbal frames are to a substantial degree more frequent in Upper Sorbian dialects than in Lower Sorbian dialects. But he did not present a general classification of Sorbian word order either. An interesting assertion about Lower Sorbian word order is to be found in the comprehensive course book Niedersorbisch schnell und intensiv by Manfred Starosta (1991), which also contains detailed information on Lower

Teichmannowa 2013).

27. Chojnan uses Latin in a very idiosyncratic way. I would like to thank the classical philologist Jürgen Buchmann for helping with the translation of many passages from the manuscript. 
Sorbian grammar. ${ }^{28}$ Starosta's notion of the Lower Sorbian word order is very significant as it takes the information structure of the sentence into account:

Die Wortfolge ist im Niedersorbischen relativ frei, da durch den morphologischen Formenreichtum die syntaktischen Beziehungen hinreichend gekennzeichnet sind. Die Abfolge der Satzglieder bzw. Wortformen im Satz ist hauptsächlich durch die aktuelle Satzgliederung bestimmt. Gewöhnlich wird bereits Bekanntes (Thema) vorangestellt und der Kern der Informationen (Rhema) steht am Satzende.

(Starosta 1991: 89)

Word Order in Lower Sorbian is relatively free because the syntactic relations [between the constituents of the sentence] are sufficiently represented by the richness of morphological forms. The order of constituents or forms of words in the sentence is primarily determined by the information structure of the sentence. Normally, the information already known is placed at the beginning of the sentence while the core of the information occurs at the end.

The traditional variety, in particular, allows for much more word order variation than its most important contact language, German. In addition, Starosta claims that the neutral word order in Lower Sorbian is SOV. ${ }^{29}$ However, field research by Michałk (1970) and Vogt (2014) on Lower Sorbian dialects yielded the result that the parts of the verb tend to appear together in the middle of the clause. Also applying features of word order typology to Lower Sorbian seems to suggest that it actually follows characteristics typical of SVO languages:

I) Except for a few adpositions which can be used both as prepositions and postpositions, like napśekor 'despite', naptošen' 'diagonally across from', napsésíwo 'across from; towards' and dla 'because of, due to', there are only prepositions (the aforementioned exceptions may have developed due to German influence).

(68) na domje

on house.LOC.SG

'on the/a house'

(69) * domje na

28. Apart from this coursebook, with extensive grammatical descriptions, only two new grammars of Lower Sorbian have been published since WW II: Niedersorbische Grammatik, LND 1976 and Pó serbsku!, LND 2017. However, the first grammar was published for teaching in the Serbska rozsyryona wuša šula 'Marjana Domaškojc' (Lower Sorbian grammar school in Cottbus) and also the latter explicitly aims at learners.

29. This view was partly shared by Arnošt Muka as early as 1915 (cf. section 1.1.) and is still very common in studies on Sorbian word order. 
II) When comparing two items, the only possible order is adjective + marker + standard of comparison.

(70) staršy nježli nan

older.NOM.SG.MASC than father.NOM.SG

'older than the father' [with reference to masculine noun]

(71) *nježli nan staršy/* nan nježli staršy

than father.NOM.SG older.NOM.SG.MASC/father.NOM.SG than older.NOM.SG.MASC

III) The genitive complement normally occurs after the nominal phrase it belongs to (72). There are, admittedly, cases where the opposite order is used (73). But this order is rare and seems to have emerged under the influence of German.

(72) syn (togo) krala son.NOM.SG (this.GEN.SG.MASC) king.GEN.SG

(73) (togo) krala syn

(this.GEN.SG.MASC) king.GEN.SG son.NOM.SG

'the son of the king'/'the king's son'

Moreover, it is very common to use possessive adjectives, as in other Slavic languages (74). The possessive adjective normally precedes the noun. The decision whether to use a genitive complement or a possessive adjective is mainly determined by the information structure of the utterance.

(74) kralowy syn

king.POSSADJ.NOM.SG.MASC son.NOM.SG

'the son of the king' / 'the king's son'

IV) The adverb can be placed before or after the word it refers to.

(75) Stary nan rédnje spiwa.

old.NOM.SG.MASC father.NOM.SG beautifully sing.3.SG.PRES

(76) Stary nan spiwa rèdnje.

old.NOM.SG.MASC father.NOM.SG sing.3.SG.PRES beautifully

'The grandfather sings / is singing beautifully.' 


\section{Conclusion}

In the present paper, syntactical features of the traditional varieties of Lower Sorbian and Breton were analysed in order to classify these minority languages typologically. Lower Sorbian has normally been described as an SOV language, yet it clearly shows more features typical of SVO languages. In addition, Lower Sorbian allows for a wide range of word order variation according to underlying information structure. In particular, word order variation for pragmatic purposes appears to play a similarly important role to that in other Slavic languages, particularly in Polish. Therefore, it is here classified as a free SVO language.

As for Breton, there are only a few cases in which a finite verb may occur at the beginning of a simple declarative sentence. However, Breton shares almost all grammatical features typical of a VSO language with its closest relatives, especially with Welsh. A reflex of its close relationship to other Insular-Celtic languages might be seen in the use of the periphrastic construction 'verbal noun + finite form of the auxiliary verb ober' which, when placed sentence-initially, is claimed to establish the most neutral word order. However, this assumption is highly controversial.

The results presented here serve as a foundation for future research on the potential development of word order in the current learner varieties of Lower Sorbian and Breton.

Universität Leipzig

\section{References}

Anderson, S. R., 2000, 'Verb-Second and Clause Structure in Breton', in: Yale University Third Celtic Linguistics Conference (available at: https://cowgill.ling.yale. edu/sra/bretonv2.pdf, last accessed 20.04.2017).

Asmus, S., 2016, 'Prolegomena to a Study of Welsh 'Central' Pronouns and Their VSO Syntax-dependent Uses', in: Bloch, M., Looby, R. \& Ó Fionnáin, M., eds., New Trails and Beaten Paths in Celtic Studies, Lublin, 107-133.

Borsley, R. D., Tallermann, M., \& Willis, D. E., 2007, 'Welsh as a VSO language', in: Borsley, R. D., Tallermann, M., \& Willis, D. E., The Syntax of Welsh, Cambridge, 338-366. Brooks, M. Z., 2013, Polish Reference Grammar, The Hague (1st edition 1975).

Bury, D., 2005, 'Preverbal Particles in Verb-initial Languages', in: Carnie, A., Harley, H., \& Dooley, S. A., Verb First: On the Syntax of Verb-Initial Languages, London, 135-154. Carnie, A, \& Guilfoyle, E., 2000, The Syntax of Verb Initial Languages, Oxford. Chalm, E., 2008, La grammaire bretonne pour tous, Lannuon/Lannion.

Chojnan, J., 1650, 'LINGVE VANDALICAE ad dialectum districtûs Cotbusiani formanda aliqualis CONATUS' [Attempt to Describe the Use of the Vandalic Language in the Dialect of Cottbus], manuscript, quoted according to the handwritten 
transcript by Hermann Lotze, 1862, Serbski kulturny archiw [Sorbian cultural archive], Bautzen.

Crystal, D., 2008, A Dictionary of Linguistics and Phonetics, Malden, Mass.

Dryer, M. S., 1991, 'SVO Languages and the OV/VO Typology', Journal of Linguistics 27, 443-482.

Dryer, M. S., 2007, 'Word Order', in: Shopen, T., ed., Clause Structure: Language Typology and Syntactic Description. Vol. 1, Cambridge (2nd ed.), 61-131.

Dryer, M. S., 2013a, 'Order of Subject, Object and Verb', in: Dryer, M. S., \& Haspelmath, M., The World Atlas of Language Structures Online, Leipzig ( available at: http://wals.info/chapter/81, last accessed 20.04.2017).

Dryer, M. S., 2013b, 'Determining Dominant Word Order', in: Dryer, M. S., \& Haspelmath, M., The World Atlas of Language Structures Online, Leipzig (available at: http://wals.info/chapter/s6, last accessed 20.04.2017).

Fabricius, J. B. / Fabricius, J. G., 1709, Das Neue Testament Unsers HErrn JEsu Christi in die Nieder=Lausitzsche Wendische Sprache übersetzet und zum Drucke befördert von Gottlieb Fabricio, Predigern in Kahren, Kahren.

Fryco, J. B. / Fritze, J. F., 1796, Bože Pißmo Starego Testamenta, Cottbus.

Ferguson, C. A., 1959, 'Diglossia', Word 15, 325-340.

Ferguson, G., 2006, Language Planning and Education, Edinburgh.

Filppula, M., Klemola, J., \& Paulasto, H. 2008, English and Celtic in Contact, London. Ar Gonidec, F./ Le Gonidec, J. F., 1827, Testamant nevez hon aotrou Jézuz-Krist, Angoulême. Ar Gonidec, F. / Le Gonidec, J. F., 1866, Testamant kozh, Saint-Brieuc. Ar Gonidec, F. / Le Gonidec, J. F., 1821, Dictionnaire celto-breton, Angoulême.

Greenberg, J., 1963, 'Some Universals of Grammar with Particular Reference to the Order of Meaningful Elements', in: Greenberg, J. H., Universals of Language, London, 73-113.

Gros, J., 1966, Le trésor du breton parlé, Brest: Emgleo Breiz.

Kervella, F., 1976, Yezhadur Bras ar Brezhoneg, Brest.

Kuter, L., 1989, 'Breton vs. French : Language and the Opposition of Political, Economic, Social, and Cultural Values', in: Dorian, N. C., ed., Investigating Obsolescence: Studies in Language Contraction and Ceath, Cambridge, 75-90.

Lotze, H., 1862, LINGVE VANDALICAE ad dialectum districtûs Cotbusiani formande aliqualis CONATUS [transcript of the original manuscript by Jan Chojnan from 1650]. Retained in the Sorbian Cultural Archive, Bautzen.

Moller, A., 1574, Ein Ewigwerender Kirchen Calender wie man den Sontags Buchstaben, die zeit zwischen dem Christage vnd Fastnacht gründtlichen erfinden möge. Auch ein Wendisches Gesangbuch, darinnen auff die Hohe Fest die Introitus, Kyrie, \& prafationes, in Lateinischer vnd Wendischer Sprache vnd die Geistliche Lieder auch etliche Psalmen Reimweise begriffen neben den Gebetlein. Auch der kleine Catechismus mit dem Tauff und Träuwbüchlein Wendisch vertiret, Bautzen. 
Michałk, F., 1970, 'K prašenjam słowoslěda w serbskich dialektach' [Word Order issues in the Sorbian dialects], Lètopis A 17, 1-29.

Muka, A., 1915, 'Městno słowjesa w serbskej sadźe' [The place of the verb in the Sorbian sentence], Časopis Maćicy Serbskeje 68, 126-139.

Ouhalla, J., 1991, Functional Categories and Parametric Variation, London.

Press, I., 1986, A Grammar of Modern Breton, Berlin.

Raney, R., 1984, 'VSO and SVO Order in Welsh and Breton', Papers and Studies in Contrastive Linguistics 18, 47-54.

Siewierska, A., \& Uhlíŕová, L., 1998, 'An Overview of Word Order in Slavic Languages', in: Siewierska, A., Constituent Order in the Languages of Europe, Berlin, 105-150.

Spiess, G., 1994, 'Sprachtod oder sprachliche Wiedergeburt? Anmerkungen zur Zukunft des Niedersorbischen', Studies in Slavic and General Linguistics 22, 389-398. Starosta, M., 1991, Niedersorbisch schnell und intensiv, Bautzen.

Stefanova, I., 2016, 'The Historical Circumstances of Coal Mining in Donbass, Lusatia and Wales', Zeszyty Eużyckie 50, Warsaw, 153-173.

Ščerba, L. V., 1915, Восточнолужицкое нарбчіе [The East-Sorbian Dialect], Petrograd. Teichmannowa, D., 2013, 'Albinus Mollerus Straupicensis: Sorabus, matematicus, astronomus, astrologus, medicus \& theologus', Rozhlad 1/2013, Domowina-Verlag, Bautzen, 7-14.

Timm, L. A., 1989, 'Word Order in 20th-century Breton', Natural Language \& Linguistic Theory 7, 361-378.

Thomason, S. G., 2001, Language Contact: An Introduction, Edinburgh.

de la Villemarqué, T. H., 1847, Dictionnaire Français-breton, Saint-Brieuc.

Trépos, P., 1980, Grammaire bretonne, Rennes.

Vogt, T., 2014, 'Słowoslěd w pódwjacornej Picańskej warietetnosći dolnoserbskeje rěcy' [Word Order in the Western Peitz Variety of Lower Sorbian], Lètopis 2014/1, Domowina-Verlag, Bautzen, 104-127.

Vogt, T., 2019, 'Early Descriptions of Lower Sorbian and Breton Syntax', in: BlochTrojnar, M., \& Ó Fionnáin, M., eds., Centres and Peripheries in Celtic Linguistics, Berlin, 143-161.

Wittmütz, V., 2007, 'Die preußische Elementarschule im 19. Jahrhundert', in: Themenportal Europäische Geschichte (available at: http://www.europa.clio-online.de/ essay/id/artikel-3406, last accessed 20.04.2017).

\section{Other online sources:}

European Charter for Regional or Minority Languages, Council of Europe (available at: http://www.coe.int/en/web/conventions/full-list/-/conventions/treaty/148/signatures, last accessed on 20.04.2017).

Trésor de la Langue Française informatisé, Université de Lorraine (available at: http:// stella.atilf.fr, last accessed on 20.04.2017). 